\title{
Protection of groundwater from migration of infiltrates from a chromic waste storage site and methods of treating these infiltrates
}

\author{
Zygmunt Kowalski, Adam Kozak, Marcin Banach, Agnieszka Makara
}

Institute of Chemistry and Inorganic Technology, Cracow University of Technology, Cracow, Poland; zkow@chemia.pk.edu.pl

Received 14 October 2009; revised 10 December 2009; accepted 14 December 2009.

\begin{abstract}
This work presents the results of investigations to develop and implement methods to effectively collect and purify infiltrates from heaps, situated in the region of Alwernia near Cracow, where more than 3 million tonnes of waste material resulting from the production of chromium compounds have been stored. It describes a system for the protection of groundwater from these infiltrates which contain $50-400 \mathrm{~g} \mathrm{~m}^{-3} \mathrm{Cr}^{6+}$, as well as the effectiveness of cheap and simple chemical methods to purify these chromic wastewaters. The infiltrate collection system and the most effective method to decrease the concentration of $\mathrm{Cr}^{6+}$ to a level below $0.1 \mathrm{ppm}$, as required by Polish and European Union regulations, were implemented in the Alwernia Chemical Works S. A. in the years 1998-1999.
\end{abstract}

Keywords: Waste Heaps; Chromic Infiltrates; Collect; Purify

\section{INTRODUCTION}

The quantities of chromic waste accumulated in Poland are considerable. In Alwernia, in the course of 50 years of production of chrome compounds, more than 3 million tonnes of waste have been stored. This waste contains more than $1 \%$ of carcinogenic $\mathrm{Cr}^{6+}$ compounds. The waste heap of a former producer of chromium compounds in Rudniki store a further 0.5 million t. Other 1.5 million $\mathrm{t}$ of waste from the production of ferro-chromium can be found in Siechnice. The amount of stored waste resulting from tanning and galvanic processes is estimated to be at least 50,000 tons per year [1-3].

Because of the position and the quantity of accumulated waste, the heap in Alwernia represents a serious hazard to the natural environment (Figure 1). The waste heap consists of two parts. The old one that was in use until 1967, and the new one, which has been in use since 1968. It is situated in the macroregion of the CracowWieluń Upland (being a layer of upper-Jurassic limestone) and the mesoregion of the Tenczyński Ridge [4,5]. The heap is located 2.5-3.0 km north of the Vistula River, in the valley of the meandering stream Regulanka. The distance between this stream and the old heap is 75 to 150 metres and that between the stream and the new heap is 75 to $200 \mathrm{~m}$. The old heap at present forms a partly recultivated block, which towers 5 meters above the level of the Chemical Works plant. The new heap forms an irregular cone with a cut top. On its slopes special terraces have been prepared to improve the stability of the slope.

In recent years efforts aiming to limit the environmental impact of chromic waste accumulated in the heaps have mostly focused on the protection of groundwater

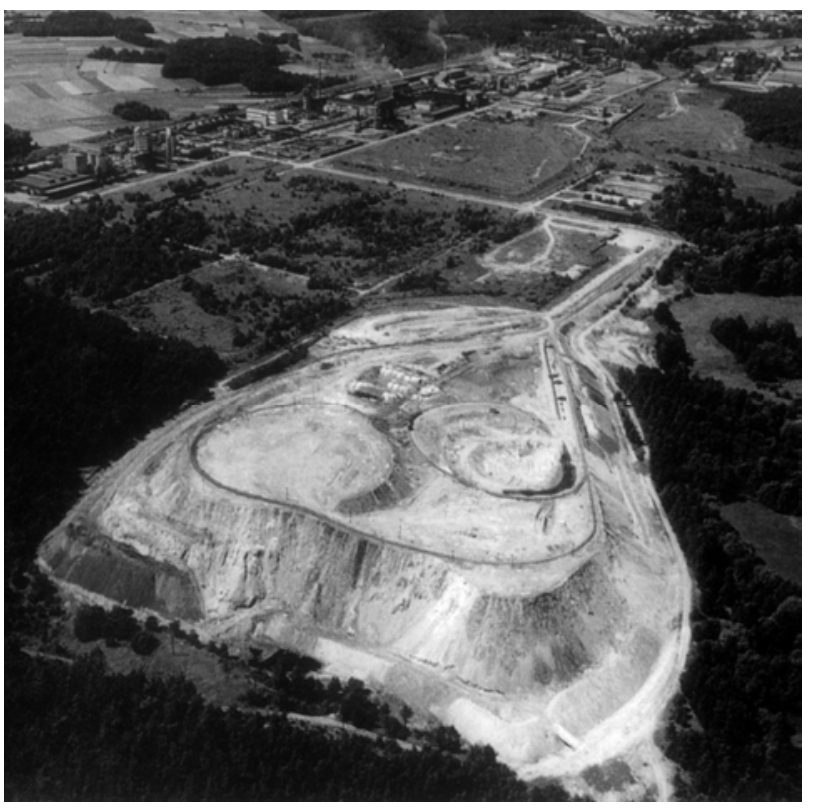

Figure 1. The "Alwernia” Chemical Works—a general view. An active heap of chromic wastes can be seen in the foreground. An old reclaimed heap occupies the area between the factory and the heap. 
against infiltration from leachates containing $\mathrm{Cr}^{6+}$ and the development of an efficient and economical method to remove chromium from these wastewaters [6,7].

The present work describes the results of investigations which led to the implementation of a collection and treatment system for infiltrates from the chromic waste dumps, containing 50 to $400 \mathrm{~g} \mathrm{~m}^{-3}$ of $\mathrm{Cr}^{6+}$. The results of experiments to devise and implement a cheap and simple method of removing chromium from wastewaters, thus reducing its concentrations below $0.1 \mathrm{ppm}$, to order to comply with Polish and European Union regulations [8], also are presented. These methods were implemented in the Chemical Works “Alwernia” in 1998/1999.

\section{RESEARCH ON THE SPREAD OF POLLUTION IN THE GROUNDWATER ENVIRONMENT IN THE REGION OF CHROMIC WASTE MATERIAL STORAGE}

The measurement of the electrical conductivity of the ground near the places of storage was conducted with the device 34-3XL produced by Geonics Ltd., Canada, based on the electromagnetic method (EM) utilising low frequencies [9]. Measurements were conducted every $20 \mathrm{~m}$ (old heap every $10 \mathrm{~m}$ ), with perpendicular arrangement of coils. The results of the specific conductivity of the ground to a depth of $15 \mathrm{~m}$ are given by Guliński et al. [6]. The graphic illustration of the results indicates the places of potential groundwater pollution (Figure 2). Maps of groundwater pollution with ions of $\mathrm{Cr}^{6+}$ have been prepared on the basis of the analysis of samples with piezometers (archival and actual), and in some cases based on EM measurements [6,7], conducted simultaneously. On the basis of these investigations, both distribution and direction of movement of pollution have been determined.

Based on the analysis of the data, a model of the distribution of under ground pollution between the Chemical Works and the Regulanka River was identified. All pollutants affecting the soil in this region permeate to the "quaternary" water-bearing layer and are then carried further by the underground waters. Between the heaps the water-bearing layers are connected by water-bearing gravel. However, the system of hydroisohypses (lines on a map joining places with the equal groundwater elevation), together with the electrical conductivity distribution, indicates a disturbance in the flow of the waters from north to south. A small hill in the neighbourhood of the southern border of the Chemical Works which is characterized by minimal thickness of "quaternary" redundant contains impenetrable formations which causes the groundwater to flow in eastern direction. It is not excluded that a part of the infiltrating wastewater flows in a south-easterly direction (Figure 2). It can be also stated

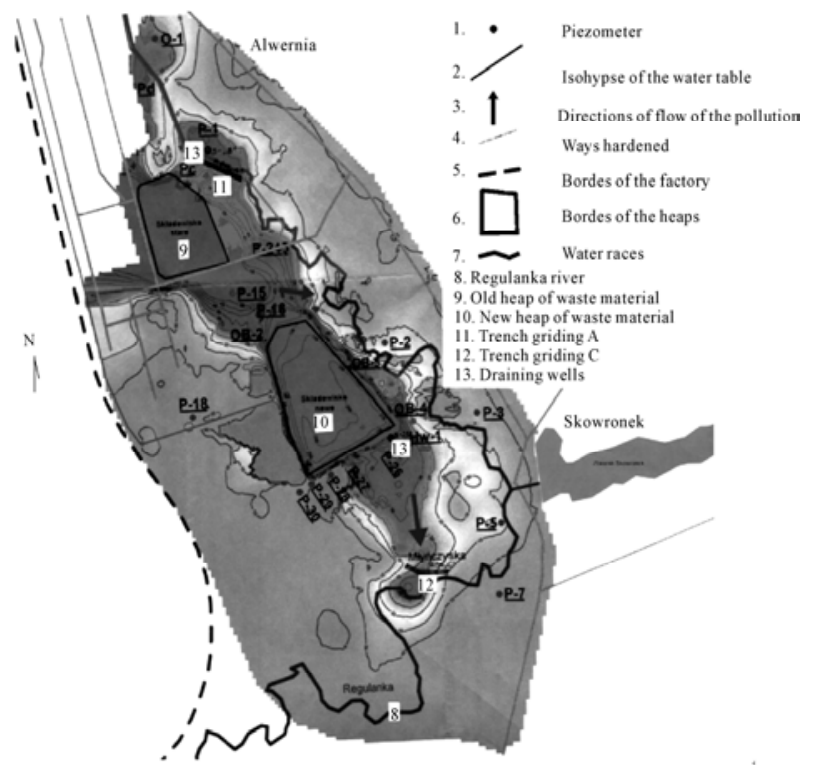

Figure 2. Distribution of chromium pollution in the vicinity of the chromic heaps at the "Alwernia" Chemical Works (according to Guliński et al. [6]).

that at the moment, in the region of Skowronek and Młyńczysko, the polluted waters from the Chemical Works are drained by the river Regulanka and carried away to the river Vistula. The hydrogeological conditions also indicate that, in the case of an attempt at regulating the riverbank and tightening its bed, the water may migrate to the Vistula through permeable sediments at the bottom of the Regulanka River valley.

The results of the investigations are presented in Figure 2. The occurrence of three streams of polluted groundwater has been identified. These are the following:

1) From the grounds of the production facilities and the northern part of old heap;

2) From the grounds of the production facilities and the southern part of old heap;

3) From the grounds of the new heap.

The main direction of the flow of pollution in the groundwater is from north to south, with some local deviations. These flow directions are indicated in Figure 2 [6].

Considering the fact that all the infiltrates might potentially enter the Vistula, the possibility of pumping these polluted waters and cleaning them, or returning them to the technological processes has been considered to be an improvement to the natural environment.

Decisions were taken to build the girding trenches "A" and "C" and the two drainage wells "B" and S-25 in 1998 and at the beginning of 1999 (Figure 2). The original plan of changing the Regulanka riverbed over a distance of 1.5 $\mathrm{km}$ has been given up. Initially, the quantity of infiltrates from these sources (intakes) was estimated to be between 600 to $2000 \mathrm{~m}^{3}$ per day. 


\section{INVESTIGATIONS INTO THE REMOVAL OF $\mathrm{Cr}^{6+}$ FROM INFILTRATES ORIGINATING FROM CHROMIC WASTE HEAPS}

Taking into consideration the fact that it is possible to reuse only $200 \mathrm{~m}^{3}$ of chromic wastewater per 24 hours in the chromium compounds production, it was decided that the only feasible possibility to solve the problem of infiltrates was to clean them from $\mathrm{Cr}^{6+}$ compounds. It was necessary, however, to develop a new method of cleaning chromic wastewaters. Such a method should be particularly adapted to low and variable chromium concentrations in wastewater and it should be cost effective to be used in practice.

The laboratory investigations were carried out on model solutions, prepared on the basis of the composition of water taken from the girding trench " $\mathrm{A}$ " in the region of the old chromic heap. The quantitative composition of the wastewater in the trench was taken from the analyses presented by Kania [7]. According to these analyses, the concentration of $\mathrm{Cr}^{6+}$ in the wastewater varied between 11 to $112.5 \mathrm{~g} \mathrm{~m}^{-3}$ in the first quarter of 1998 . The $\mathrm{SO}_{4}{ }^{2-}$ anions in concentrations of 240 to $555 \mathrm{~g} \mathrm{~m}^{-3}$ can also be found in wastewater, and their presence has to be taken into consideration for the successful removal of chromate anions from the solution.

In previous years the "Alwernia" Chemical Works investigated ways of cleaning the wastewaters which contained more than $1 \mathrm{~kg} \mathrm{~m}^{-3}$ of $\mathrm{Cr}^{6+}$, using a classical chemical method, based on the reduction of $\mathrm{Cr}^{6+}$ to $\mathrm{Cr}^{3+}$ and the precipitation of $\mathrm{Cr}(\mathrm{OH})_{3}$. Sodium sulphite was used as a reducing agent at a pH between 2 and 4. Precipitation of the reduced chromium as a chromium (III) hydroxide was then accomplished with the use of calcium oxide [10].

The results of the laboratory investigations [11] on model solutions containing $\mathrm{Cr}^{6+}$ ions in concentrations of 50 to $200 \mathrm{~g} \mathrm{~m}^{-3}$ show that with the use of both, sodium sulphite and sodium pyrosulfite $\left(\mathrm{Na}_{2} \mathrm{~S}_{2} \mathrm{O}_{5}\right)$ as a reducing agent, lowering of the concentration of $\mathrm{Cr}^{6+}$ below $1 \mathrm{~g} \mathrm{~m}^{-3}$ was possible. In almost all the experiments between 1 and $12.5 \mathrm{~g} \mathrm{~m}^{-3}$ of $\mathrm{Cr}^{6+}$ were left in the solution after the reduction, and in most of the analyses the concentration of $\mathrm{Cr}^{6+}$ ranged from 1 to $3 \mathrm{~g} \mathrm{~m}^{-3}$, with a tendency towards higher values.

Many authors suggest the use of anion exchangers to remove $\mathrm{Cr}^{6+}$ [12-16]. The advantage of this method is that the $\mathrm{Cr}^{6+}$ compounds in the solution used to regenerate the anion exchanger are more concentrated than in the original wastewater. In the case of diluted wastewaters containing considerable quantities of suspended solids, this method is not practical because it requires the use of very large columns and the anion exchanger could be blocked by the suspended solid matter present in the infiltrates thus resulting in an increase in flow resistance.

What is suggested most often is the purification of chromic wastewater by reducing hexavalent chromium to trivalent chromium in an acid environment and then precipitating the latter as chromium (III) hydroxide. In addition to the above-mentioned sodium sulphite and pyrosulfite, the use of the reducing agents sulphur dioxide $\left(\mathrm{SO}_{2}\right)$ and sodium acid sulphate $\left(\mathrm{NaHSO}_{3}\right)$ at a lower $\mathrm{pH}$ range (2-2.5) is recommended [17-19].

Reduction of $\mathrm{Cr}^{6+}$ to $\mathrm{Cr}^{3+}$ may also be achieved in a basic environment using iron (II) sulphate as a reducing agent [14]. This reaction follows the equation:

$\mathrm{CrO}_{4}{ }^{2-}+3 \mathrm{Fe}^{2+}+4 \mathrm{OH}^{-}+4 \mathrm{H}_{2} \mathrm{O}=\mathrm{Cr}(\mathrm{OH})_{3}+3 \mathrm{Fe}(\mathrm{OH})_{3}(1)$

Another interesting possibility of chromium removal is the precipitation of chromium from wastewater in the form of chromic ettryngite. This method can be used to purify chromic tanning wastewater containing $\mathrm{Cr}^{3+}$ [20-22]. The occurrence of ettryngite was first observed in the research on cement mortar. Its chemical formula is $2 \mathrm{CaO} \cdot \mathrm{Al}_{2} \mathrm{O}_{3} \cdot 3 \mathrm{CaSO}_{4} \cdot 32 \mathrm{H}_{2} \mathrm{O}$ [23,24]. Ettryngite forms during cement bonding and also after mixing of ashes from fluidised hearths with water [25]. It was stated by several authors that the aluminium in ettryngite can be substituted by $\mathrm{Fe}^{3+}, \mathrm{Cr}^{3+}$ and other metal ions [26-29]. Furthermore, the $\mathrm{SO}_{4}{ }^{2-}$ ion can be exchanged by other anions, i.e. chromate $\mathrm{CrO}_{4}^{2-}$ [24-30]. In spite of some qualitative changes, such a compound retains the same structure. According to the above-mentioned authors the requirement for the formation of this compound, generally called ettryngite, is a high $\mathrm{pH}$, and the maintenance of a $\mathrm{CaO}: \mathrm{Me}_{2} \mathrm{O}_{3}$ :anion(II) ratio of 6:2:3. A practical example of the use of the ettryngite precipitation to remove $\mathrm{SO}_{4}{ }^{2-}$ ions from wastewater has been presented by Woroszyńska et al. [31].

Among the chemical methods, the possibility of precipitating chromate after first converting it into compounds with a very low solubility product, i.e. $\mathrm{BaCrO}_{4}$ or $\mathrm{PbCrO}_{4}$ [32], should also be mentioned.

Four methods to purify wastewater containing $\mathrm{Cr}^{6+}$ compounds were tested under laboratory conditions in the "Alwernia” Chemical Works. Two of them were based on the incorporation of the $\mathrm{CrO}_{4}{ }^{2-}$ ion into the ettryngite structure, in the presence of aluminium or iron (III) salts in a basic environment, and its subsequent precipitation. Another method was based on the precipitation of the ion of $\mathrm{CrO}_{4}{ }^{2-}$ by lead salts, utilising the low solubility of lead chromate. The last method was carried out in two stages: in the first stage the $\mathrm{Cr}^{6+}$ ion was reduced with iron (II) salts, after which the chromium ion was precipitated by adding $\mathrm{CaO}$ to the solution. The investigations were conducted at temperatures between 291 and $295 \mathrm{~K}$. Modelling solutions and wastewater from the band trench " $\mathrm{A}$ " in the "Alwernia" Chemical Works were used in our investigations. 


\subsection{Attempts at Removing Chromate Lons by Incorporating Them into the Ettryngite Structure}

\subsubsection{Attempts to Produce Chromic-Aluminium Ettryngite}

The first experiments were carried out with $250 \mathrm{~cm}^{3}$ of model solutions prepared from potassium or sodium chromate, with concentrations of $\mathrm{Cr}^{6+}$ equal to 10,50 and $100 \mathrm{~g} \mathrm{~m}^{-3}$. These concentrations corresponded to the $\mathrm{Cr}^{6+}$ concentrations in the wastewater in the band trench " $\mathrm{A}$ " during the period of January to March 1998 [7].

The following method was used:

Calcium oxide in the solid state was added to solutions containing $\mathrm{Cr}^{6+}$ in the above-mentioned concentrations. The solutions were then mixed for two hours, after which $\mathrm{Al}\left(\mathrm{NO}_{3}\right)_{3} \cdot 9 \mathrm{H}_{2} \mathrm{O}$ was introduced. In some investigations solid $\mathrm{NaOH}$ was added in order to obtain higher basicity. Theoretically, the molar ratio of each component, i.e. $\mathrm{CaO}$, $\mathrm{Al}^{3+}$ and $\mathrm{CrO}_{4}{ }^{2+}$ in ettryngite should be 6:2:3. In the initial investigations an ettryngite structure was formed when $\mathrm{CaO}$ and $\mathrm{Al}\left(\mathrm{NO}_{3}\right)_{3} \cdot 9 \mathrm{H}_{2} \mathrm{O}$ were added in excess by about 20-30 \% (Figure 3(a)). However, the concentration of $\mathrm{Cr}^{6+}$ ions in the filtrate still exceeded the permitted concentrations $(<0.1 \mathrm{ppm})$, although it was possible to remove up to about $99 \%$ of $\mathrm{CrO}_{4}{ }^{2-}$ ions (Table 1).

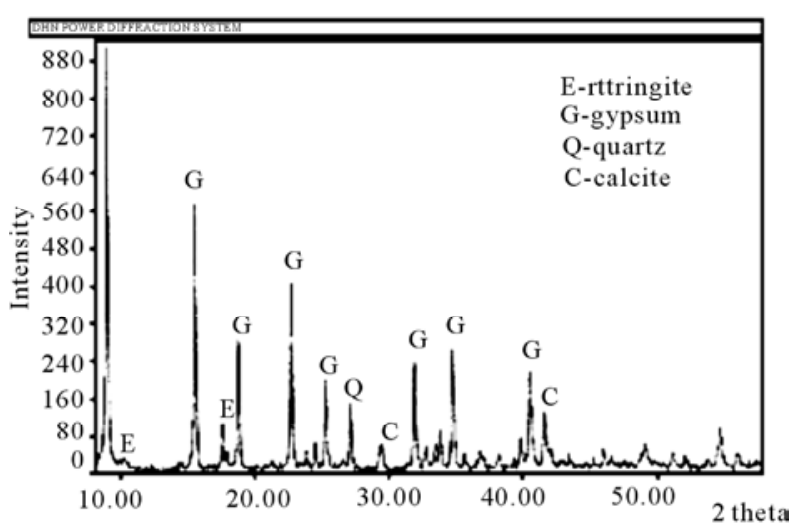

(a)

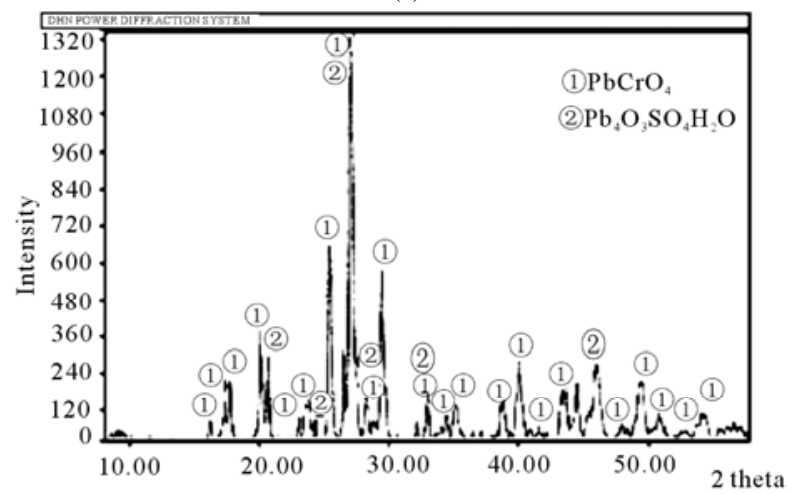

(b)

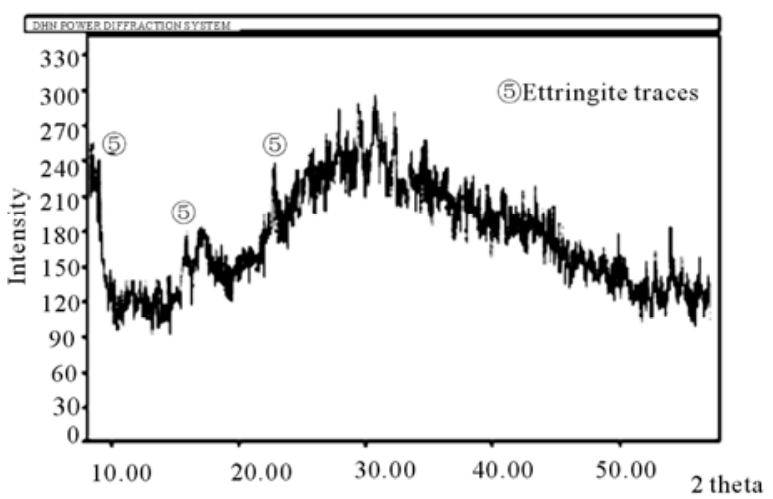

(c)

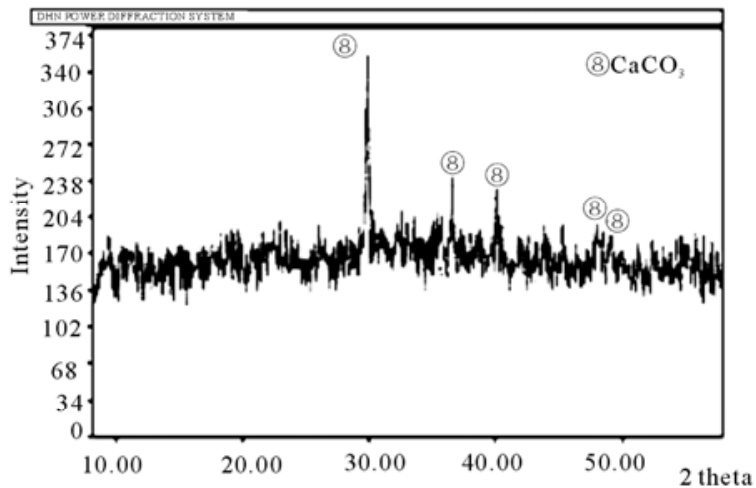

(d)

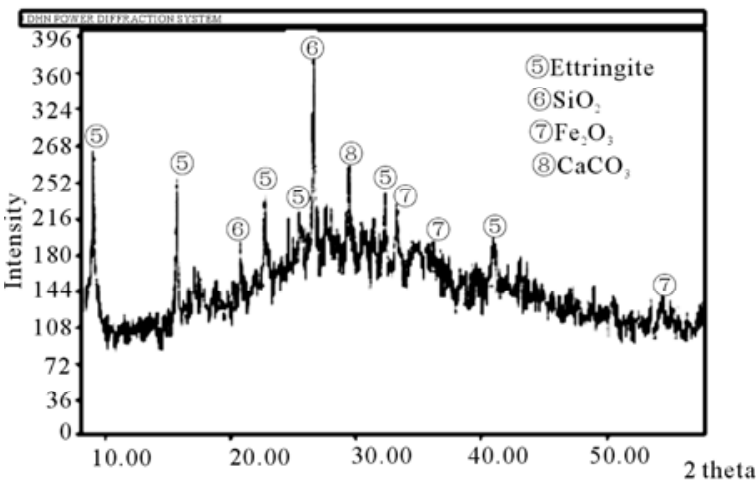

(e)

Figure 3. Results of the X-ray analyses of precipitates from the purification of the infiltrates from chromic heaps. (a) Precipitate consisting of chromic-aluminium ettryngite; (b) Precipitate consisting of lead chromate; (c) Sample of the solid phase after the reduction of chromium (VI) to chromium (III) with simultaneous precipitation of the latter; (d) Sample is desiccated at a temperature $378 \mathrm{~K}$; (e) Sample of the solid phase precipitated with the ash from fluidised bed instead of calcium hydroxide.

Results of analyses reported by Kania [7] show that the wastewater from the band trench "A" also contains sulphates $\left(\mathrm{SO}_{4}{ }^{2-}\right)$, and their molar ratio to $\mathrm{CrO}_{4}{ }^{2-}$ ions varies from $5: 1$ to $10: 1$. No information was found in the literature about differences in properties between the ettryngite containing $\mathrm{SO}_{4}{ }^{2-}$ or $\mathrm{CrO}_{4}{ }^{2-}$ and from the results of 
our initial investigations it can be concluded that their properties are similar. Therefore, the quantities of added $\mathrm{CaO}$ and aluminium salts were referred to the sum of moles of $\mathrm{CrO}_{4}{ }^{2-}$ and $\mathrm{SO}_{4}{ }^{2-}$ in subsequent experiments. The results of investigations carried out on model solutions containing $104 \mathrm{mg}$ of $\mathrm{Cr}^{6+}$ and $960 \mathrm{mg}$ of $\mathrm{SO}_{4}{ }^{2-}$ in one litre of solution have been summarised in Table 2 and the results of investigations conducted on the wastewater from trench "A" are presented in Table 3. In none of the above-mentioned investigations (with the exception of two-Table 1, No. 3 and 4), results below $1 \mathrm{~g} \mathrm{~m}^{-3} \mathrm{Cr}^{6+}$ were obtained. Using large excesses of added aluminium salts and calcium oxide only resulted in concentrations of $\mathrm{Cr}^{6+}$ in the range of $1 \mathrm{~g} \mathrm{~m}^{-3}$ (Table 3 ).

When aluminium salts were added in excess of amounts theoretically needed for ettryngite formation, aluminium appeared in the filtrate. This was a result of the high $\mathrm{pH}$ of the solution, at which aluminium exists in the $\mathrm{AlO}_{2}^{-}$form.

\subsubsection{Attempts to Produce Iron-Chromic Ettryngite}

Several experiments were conducted to synthesise a compound composed of $3 \mathrm{CaO} \cdot \mathrm{Fe}_{2} \mathrm{O}_{3} \cdot 2 \mathrm{CaSO}_{4} \cdot \mathrm{nH}_{2} \mathrm{O}$, in which aluminium was substituted by the less amphoteric iron (III) (some authors are of the opinion that iron (III) is not even amphoteric [17]). The influence of iron (III)added as iron (III) chloride-was tested on a model solution containing $104 \mathrm{mg}$ of $\mathrm{Cr}^{6+}$ and $960 \mathrm{mg}$ of $\mathrm{SO}_{4}{ }^{2-}$ in one litre. The objective of the investigations was to determine the most economic ratio of calcium oxide and iron chloride added in relation to the sum of the ions of $\mathrm{CrO}_{4}{ }^{2-}$ and $\mathrm{SO}_{4}{ }^{2-}$ for the effective removal of $\mathrm{Cr}^{6+}$ ions. The experiments were also conducted on industrial wastewater containing $38.26 \mathrm{~g} \mathrm{~m}^{-3}$ of $\mathrm{Cr}^{6+}$. All investigations were conducted in a manner similar to the previous ones: a weighed amount of $\mathrm{CaO}$ was added to the $\mathrm{Cr}^{6+}$ solution and the solution was mixed. After 1 to 2 hours $\mathrm{FeCl}_{3} \cdot 6 \mathrm{H}_{2} \mathrm{O}$ was added and the solution was mixed for a further 0.5 to 1.0 hours. The results of the investigations obtained with the model solutions are given in Table 4, and the results obtained with wastewater are presented in Table 5. Some improvement of filtrate quality can be observed. At a molar ratio of $\mathrm{CaO}$ and $\mathrm{FeCl}_{3} \cdot 6 \mathrm{H}_{2} \mathrm{O}$ to the sum of chromates and sulphate equalling 20:1 and 3:1, respectively, the removal of the $\mathrm{Cr}^{6+}$ ions from the solution is about $94 \%$.

\subsection{Precipitation of Chromate Lons in Form of Sparingly Soluble Compounds}

According to Ufimciewa and Smietanic [19], lead chromate is a sparingly soluble compound with a solubility product of $1.8 \times 10^{-14}$. Thus, in the presence of lead the precipitation of $\mathrm{CrO}_{4}{ }^{2-}$ with subsequent decrease of $\mathrm{Cr}^{6+}$ to values below $1 \mathrm{~g} \mathrm{~m}^{-3} \mathrm{Cr}^{6+}$ is expected. The tests with model solutions rendered the expected results. The model solution contained $0.194 \mathrm{~g}$ of $\mathrm{K}_{2} \mathrm{CrO}_{4}$ and $1.62 \mathrm{~g}$ of
$\mathrm{Na}_{2} \mathrm{SO}_{4} \cdot 10 \mathrm{H}_{2} \mathrm{O}$ in $500 \mathrm{~cm}^{3}$ of water, which corresponded to concentrations of $\mathrm{Cr}^{6+}$ ions equal to $104 \mathrm{~g} \mathrm{~m}^{-3}$ and $\mathrm{SO}_{4}{ }^{2-}$ ions equal to $960 \mathrm{~g} \mathrm{~m}^{-3}$. Solid $\mathrm{PbCl}_{2}$ was added to the solution. The molar ratios of $\mathrm{Pb}^{2+}: \mathrm{Cr}^{6+}$ were 1.5:1, 2.0:1 and 2.5:1. The solution was then mixed for two hours, after which the coagulant was introduced. Separating the solid phase from the solution did not present any difficulties. Filtrate analysis showed $\mathrm{Cr}^{6+}$ concentrations of $0.99,0.27$ and $0.025 \mathrm{~g} \mathrm{~m}^{-3}$ for the $\mathrm{Pb}^{2+}: \mathrm{Cr}^{6+}$ ratios 1.5:1, 2.0:1 and $2.5: 1$, respectively. Further experiments were conducted with wastewater from the trench " $\mathrm{A}$ ", which had a $\mathrm{Cr}^{6+}$ concentration of $17.28 \mathrm{~g} \mathrm{~m}^{-3}$. The molar ratios of $\mathrm{Pb}^{2+}: \mathrm{Cr}^{6+}$ were 1.5:1, 2.0:1 and 2.5:1. The best results were obtained when 2.5 moles of lead chloride were introduced per 1 mole of $\mathrm{Cr}^{6+}$ (about $97 \%$ of $\mathrm{Cr}^{6+}$ removal).

The quality of the filtrate is also influenced by its $\mathrm{pH}$. The $\mathrm{pH}$ of the wastewater is weakly alkaline and under these conditions the formation and precipitation of lead hydroxide takes place (solubility product equal to $1.1 \times$ $10^{-20}$ ) thus reducing the participation of lead (II) in the formation of lead chromate, which results in an incomplete removal of $\mathrm{CrO}_{4}{ }^{2-}$ from the solution. Under acidic conditions $(\mathrm{pH}<4) \mathrm{Cr}^{6+}$ ions are still present in the solution. Therefore, the most profitable precipitating conditions are obtained at a pH between 4 and 6 (acidification of the wastewater with 2-3 drops of concentrated muriatic acid). However, the presence of $\mathrm{SO}_{4}{ }^{2-}$ in the wastewater causes the precipitation of $\mathrm{Pb}^{2+}$ ions as hardly soluble lead sulphate $\left(\mathrm{I}_{\mathrm{r}}=1.6 \times 10^{-8}\right)$, thus reducing the efficiency of this method. The results of the experiments are presented in Table 6. The best treatment results $\left(\mathrm{Cr}^{6+}\right.$ content below0.1 ppm) are obtained when molar ratio $\mathrm{Pb}^{2+} / \mathrm{Cr}^{6+}$ was 2.5: 1 and $\mathrm{pH}$ was between 5.0 and 6.1. X-ray analysis shows (Figure 3(b)) that the precipitate consists of lead chro mate $\left(\mathrm{PbCrO}_{4}\right)$ and of another, not precisely identified, solid phase, probably $\mathrm{Pb}_{4} \mathrm{O}_{3} \mathrm{SO}_{4} \cdot \mathrm{H}_{2} \mathrm{O}$.

\subsection{The Reduction of $\mathrm{Cr}^{6+}$ to $\mathrm{Cr}^{3+}$ in Alkaline Environment with Simultaneous Precipitation of $\mathrm{Cr}(\mathrm{OH})_{3}$}

The reduction of $\mathrm{Cr}^{6+}$ to $\mathrm{Cr}^{3+}$ with simultaneous precipitation of the latter can be described by the following equation:

$$
\begin{aligned}
& \mathrm{Na}_{2} \mathrm{CrO}_{4}+2 \mathrm{Ca}(\mathrm{OH})_{2}+3 \mathrm{FeSO}_{4}+8 \mathrm{H}_{2} \mathrm{O}=\mathrm{Cr}(\mathrm{OH})_{3}+3 \mathrm{Fe}(\mathrm{OH})_{3} \\
& +2 \mathrm{CaSO}_{4} \cdot 2 \mathrm{H}_{2} \mathrm{O}+\mathrm{Na}_{2} \mathrm{SO}_{4}
\end{aligned}
$$

To determine the optimum quantities of iron (II) sulphates and calcium hydroxide, the experiments were initially conducted with model solutions. The solution simulating wastewater contained potassium chromate and sodium sulphate in concentrations corresponding to 104 $\mathrm{mg} \mathrm{Cr}^{6+}$ and $960 \mathrm{mg}$ of $\mathrm{SO}_{4}{ }^{2-}$ in one litre of the solution. The added components are subsequently only referred to as $\mathrm{Cr}^{6+}$. In a first attempt calcium hydroxide was added to the solution in a molar ratio of $\mathrm{Ca}(\mathrm{OH})_{2}$ to $\mathrm{Cr}^{6+}$ of $25: 1$. 
Table 1. Results of experiments to optimise the quantities of $\mathrm{CaO}$ and $\mathrm{Al}\left(\mathrm{NO}_{3}\right)_{3} \cdot 9 \mathrm{H}_{2} \mathrm{O}$ necessary to remove chromate ions from model solutions (initial volume $250 \mathrm{~cm}^{3}$ ) by formation of chromic-aluminium ettryngite.

\begin{tabular}{|c|c|c|c|c|c|c|c|c|c|c|c|}
\hline \multirow[t]{2}{*}{ No. } & \multirow[t]{2}{*}{$\begin{array}{c}\text { Initial } \\
\text { concentration of } \mathrm{Cr}^{6+} \\
{\left[\mathrm{g} \mathrm{m}^{-3}\right]}\end{array}$} & \multicolumn{2}{|c|}{$\begin{array}{c}\text { Quantity of } \\
\text { added compounds } \\
\text { [g] }\end{array}$} & \multicolumn{2}{|c|}{ Molar ratios } & \multicolumn{6}{|c|}{ Filtrate characteristics } \\
\hline & & $\mathrm{CaO}$ & $\mathrm{Al}\left(\mathrm{NO}_{3}\right)_{3} \cdot 9 \mathrm{H}_{2} \mathrm{O}$ & $\mathrm{CaO} / \mathrm{Cr}^{6+}$ & $\mathrm{Al}^{3+} / \mathrm{Cr}^{6+}$ & $\begin{array}{c}\mathrm{Cr}^{6+} \\
{\left[\mathrm{g} \mathrm{m}^{-3}\right]}\end{array}$ & $\begin{array}{c}\mathrm{Al}^{3+} \\
{\left[\mathrm{g} \mathrm{m}^{-3}\right]}\end{array}$ & $\begin{array}{c}\mathrm{CaO} \\
{\left[\mathrm{g} \mathrm{m}^{-3}\right]}\end{array}$ & $\mathrm{pH}$ & $\begin{array}{l}\mathrm{NaOH} \\
\text { addition } \\
\text { [g] }\end{array}$ & $\begin{array}{l}\mathrm{pH} \text { after } \\
\mathrm{NaOH} \\
\text { addition }\end{array}$ \\
\hline 1 & 10 & 0.088 & 0.188 & $31: 1$ & $10: 1$ & 3.30 & 58.0 & 4.2 & 10.70 & 0.2 & 11.75 \\
\hline 2 & 10 & 0.088 & 0.188 & $31: 1$ & $10: 1$ & 3.22 & 35.0 & 31.0 & 10.88 & 0.2 & 11.78 \\
\hline 3 & 10 & 0.176 & 0.376 & $63: 1$ & $20: 1$ & 0.11 & 24.5 & 78.4 & 11.37 & 0.2 & 11.93 \\
\hline 4 & 50 & 0.220 & 0.470 & $16: 1$ & $5: 1$ & 0.92 & 12.0 & 19.6 & 11.09 & 0.2 & 11.86 \\
\hline 5 & 100 & 0.440 & 0.940 & $16: 1$ & $5: 1$ & 1.21 & 16.0 & 234.0 & 10.98 & 0.2 & 11.71 \\
\hline 6 & 100 & 0.440 & 0.940 & $16: 1$ & $5: 1$ & 1.15 & 52.0 & 204.4 & 11.03 & 02 & 11.04 \\
\hline 7 & 100 & 0.440 & 0.940 & $16: 1$ & $5: 1$ & 1.08 & 11.0 & 447.0 & 11.17 & 0.2 & 11.98 \\
\hline 8 & 100 & 0.440 & 0.940 & $16: 1$ & $5: 1$ & 1.26 & 3.5 & 2.8 & 10.77 & 0.4 & 12.00 \\
\hline
\end{tabular}

Table 2. Results of experiments to optimise the quantities of $\mathrm{CaO}$ and $\mathrm{AlCl}_{3} \cdot 6 \mathrm{H}_{2} \mathrm{O}$ necessary to remove chromate ions from a model solution containing $104 \mathrm{~g} \mathrm{~m}^{-3} \mathrm{Cr}^{6+}$ and $960 \mathrm{~g} \mathrm{~m}^{-3} \mathrm{SO}_{4}^{2-}$ (initial volume $250 \mathrm{~cm}^{3}$ ) by formation of chromic-aluminium ettryngite.

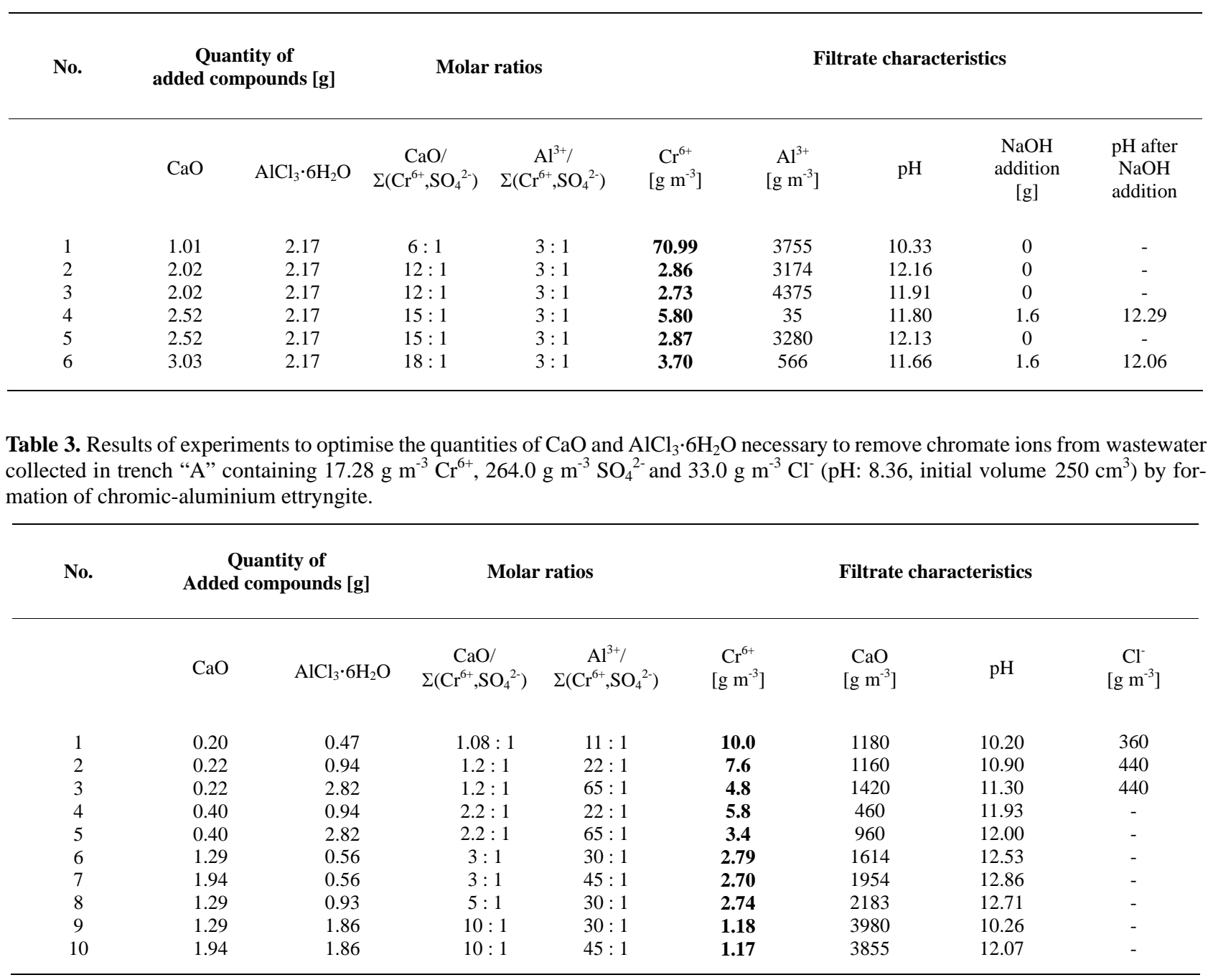


Table 4. Results of experiments to optimise the quantities of $\mathrm{CaO}$ and $\mathrm{FeCl}_{3} \cdot 6 \mathrm{H}_{2} \mathrm{O}$ necessary to remove chromate ions from a model solution containing $104 \mathrm{~g} \mathrm{~m}^{-3} \mathrm{Cr}^{6+}$ and $960 \mathrm{~g} \mathrm{~m}^{-3} \mathrm{SO}_{4}{ }^{2-}$ (initial volume $250 \mathrm{~cm}^{3}$ ) by formation of chromic-iron ettryngite.

\begin{tabular}{|c|c|c|c|c|c|c|c|c|}
\hline \multirow[t]{2}{*}{ No. } & \multicolumn{2}{|c|}{$\begin{array}{l}\text { Quantity of added } \\
\text { compounds [g] }\end{array}$} & \multicolumn{2}{|c|}{ Molar ratios } & \multicolumn{4}{|c|}{ Filtrate characteristics } \\
\hline & $\mathrm{CaO}$ & $\mathrm{FeCl}_{3} \cdot 6 \mathrm{H}_{2} \mathrm{O}$ & $\begin{array}{c}\mathrm{CaO} / \\
\Sigma\left(\mathrm{Cr}^{6+}, \mathrm{SO}_{4}{ }^{2-}\right)\end{array}$ & $\begin{array}{c}\mathrm{Fe}^{3+} / \\
\Sigma\left(\mathrm{Cr}^{6+}, \mathrm{SO}_{4}{ }^{2-}\right)\end{array}$ & $\begin{array}{c}\mathrm{Cr}^{6+} \\
{\left[\mathrm{g} \mathrm{m}^{-3}\right]}\end{array}$ & $\mathrm{CaO}\left[\mathrm{g} \mathrm{m}^{-3}\right]$ & $\begin{array}{c}\mathrm{Fe}^{3+} \\
{\left[\mathrm{g} \mathrm{m}^{-3}\right]}\end{array}$ & $\mathrm{pH}$ \\
\hline 1 & 1.68 & 0.81 & $10: 1$ & $1: 1$ & 20.30 & 2182 & $<0.01$ & 12.05 \\
\hline 2 & 3.36 & 0.81 & $20: 1$ & $1: 1$ & 19.42 & 2416 & $<0.01$ & 12.22 \\
\hline 3 & 5.04 & 0.81 & $30: 1$ & $1: 1$ & 17.99 & 2468 & $<0.01$ & 12.31 \\
\hline 4 & 1.68 & 1.62 & $10: 1$ & $2: 1$ & 4.08 & 2311 & $<0.01$ & 12.27 \\
\hline 5 & 3.36 & 1.62 & $20: 1$ & $2: 1$ & 4.93 & 2423 & 0.05 & 12.39 \\
\hline 6 & 1.68 & 2.43 & $10: 1$ & $3: 1$ & 4.36 & 2971 & 0.17 & 11.73 \\
\hline 7 & 1.68 & 2.43 & $10: 1$ & $3: 1$ & 5.17 & 2782 & 0.28 & 12.27 \\
\hline 8 & 3.36 & 2.43 & $20: 1$ & $3: 1$ & 3.68 & 3672 & 0.02 & 12.25 \\
\hline 9 & 3.36 & 2.43 & $20: 1$ & $3: 1$ & 1.13 & 3073 & 0.02 & 12.42 \\
\hline 10 & 5.04 & 2.43 & $30: 1$ & $3: 1$ & 3.95 & 3681 & 0.18 & 12.35 \\
\hline 11 & 2.52 & 3.24 & $15: 1$ & $4: 1$ & 3.18 & 4105 & $<0.01$ & 12.43 \\
\hline 12 & 3.36 & 3.24 & $20: 1$ & $4: 1$ & 1.02 & 3679 & 0.18 & 12.48 \\
\hline 13 & 5.04 & 3.24 & $30: 1$ & $4: 1$ & 1.62 & 4979 & $<0.01$ & 12.25 \\
\hline 14 & 1.68 & 4.05 & $10: 1$ & $5: 1$ & 19.83 & 5087 & 0.30 & 11.62 \\
\hline 15 & 3.36 & 4.05 & $20: 1$ & $5: 1$ & 1.25 & 5045 & 0.08 & 12.33 \\
\hline 16 & 3.36 & 4.05 & $20: 1$ & $5: 1$ & 1.07 & 5549 & $<0.01$ & 12.30 \\
\hline 17 & 5.04 & 4.05 & $30: 1$ & $5: 1$ & 1.24 & 5434 & $<0.01$ & 12.28 \\
\hline
\end{tabular}

Table 5. Results of experiments to optimise the quantities of $\mathrm{CaO}$ and $\mathrm{FeCl}_{3} \cdot 6 \mathrm{H}_{2} \mathrm{O}$ necessary to remove chromate ions from wastewater collected in trench "A" containing $38.26 \mathrm{~g} \mathrm{~m}^{-3} \mathrm{Cr}^{6+}, 407.0 \mathrm{~g} \mathrm{~m}^{-3} \mathrm{SO}_{4}{ }^{2-}$ and $43.0 \mathrm{~g} \mathrm{~m}^{-3} \mathrm{Cl}^{-}$(initial $\mathrm{pH}$ : 7.97, initial volume $250 \mathrm{~cm}^{3}$ ) by formation of chromic-iron ettryngite.

\begin{tabular}{|c|c|c|c|c|c|c|c|c|}
\hline \multirow[t]{2}{*}{ No. } & \multicolumn{2}{|c|}{$\begin{array}{l}\text { Quantity of added } \\
\text { compounds [g] }\end{array}$} & \multicolumn{2}{|c|}{ Molar ratios } & \multicolumn{4}{|c|}{ Filtrate characteristics } \\
\hline & $\mathrm{CaO}$ & $\mathrm{FeCl}_{3} \cdot 6 \mathrm{H}_{2} \mathrm{O}$ & $\begin{array}{c}\mathrm{CaO} / \\
\Sigma\left(\mathrm{Cr}^{6+}, \mathrm{SO}_{4}{ }^{2-}\right)\end{array}$ & $\begin{array}{c}\mathrm{Fe}^{3+} / \\
\Sigma\left(\mathrm{Cr}^{6+}, \mathrm{SO}_{4}^{2-}\right)\end{array}$ & $\begin{array}{c}\mathrm{Cr}^{6+} \\
{\left[\mathrm{g} \mathrm{m}^{-3}\right]}\end{array}$ & $\begin{array}{l}\mathrm{Ca}^{2+} \\
{\left[\mathrm{g} \mathrm{m}^{-3}\right]}\end{array}$ & $\begin{array}{c}\mathrm{Fe}^{3+} \\
{\left[\mathrm{g} \mathrm{m}^{-3}\right]}\end{array}$ & $\mathrm{pH}$ \\
\hline 1 & 0.697 & 1.01 & $10: 1$ & $3: 1$ & 3.66 & 1715 & 0.02 & 11.72 \\
\hline 2 & 0.697 & 1.01 & $10: 1$ & $3: 1$ & 3.77 & 997 & 0.02 & 11.63 \\
\hline 3 & 1.046 & 1.01 & $15: 1$ & $3: 1$ & 2.38 & 2464 & 0.02 & 12.53 \\
\hline 4 & 1.046 & 1.01 & $15: 1$ & $3: 1$ & 2.34 & 2410 & 0.14 & 12.26 \\
\hline 5 & 1.395 & 1.01 & $20: 1$ & $3: 1$ & 2.08 & 2492 & 0.03 & 12.40 \\
\hline 6 & 1.395 & 1.01 & $20: 1$ & $3: 1$ & 2.23 & 2558 & 0.02 & 12.37 \\
\hline
\end{tabular}

The molar ratio of $\mathrm{FeSO}_{4} \cdot 7 \mathrm{H}_{2} \mathrm{O}$ to $\mathrm{Cr}^{6+}$ was $6: 1$. After addition of calcium hydroxide, the solution was mixed for two hours, then solid iron (II) sulphate was also introduced. After a few minutes the formation of the solid phase was noticed, and after another two hours and addition of a coagulator a separation of the solid phase from the solution was observed. The solution was clear and colourless. The content of $\mathrm{Cr}^{6+}$ in the solution was barely detectable. Using model solutions, further experiments were conducted to determine the smallest quantities of iron sulphate and calcium hydroxide necessary to decrease the "solutions" $\mathrm{Cr}^{6+}$ concentrations below 0.1 ppm. The order in which iron (II) sulphate and calcium hydroxide were added were also changed, but it did not affect the results when the molar ratio iron (II) sulphate to chromium (VI) was equal to or greater than 5.5. At lower ratios it seems more effective to introduce $\mathrm{FeSO}_{4} \cdot 7 \mathrm{H}_{2} \mathrm{O}$ first. Also the quality of iron (II) sulphate influences the quantity of iron (II) sulphate necessary to remove $\mathrm{Cr}^{6+}$. When ash containing the required quantity of $\mathrm{CaO}$ was used instead of calcium hydroxide, a very good solid phase separation was achieved without the use of a coagulator. The results of the investigations are presented in Table 7. At molar ratio of $\mathrm{Ca}(\mathrm{OH})_{2}$ to $\mathrm{Cr}^{6+}$ and $\mathrm{Fe}^{3+}$ to $\mathrm{Cr}^{6+}$ equal to or higher than 20:1 and 5.4:1, respectively, the concentration of the $\mathrm{Cr}^{6+}$ ions in the filtrate is below $0.01 \mathrm{ppm}$, which is lower than required by the Polish and European regulations. 
Table 6. Results of experiments to optimise $\mathrm{pH}$ and $\mathrm{Pb}^{2+} / \mathrm{Cr}^{6+}$ ratio in order to remove chromate ions from wastewater collected in trench " $\mathrm{A}$ " containing $264.0 \mathrm{~g} \mathrm{~m}^{-3} \mathrm{Cr}^{6+}$ and $33.0 \mathrm{~g} \mathrm{~m}^{-3}$ $\mathrm{SO}_{4}{ }^{2-}$ (initial $\mathrm{pH}$ : 7.28, initial volume $250 \mathrm{~cm}^{3}$ ) by precipitation as lead chromate.

\begin{tabular}{cccccc}
\hline No. & $\begin{array}{c}\text { Molar ratio } \\
\mathrm{Pb}^{2+} / \mathrm{Cr}^{6+}\end{array}$ & $\begin{array}{c}\text { pH after } \\
\text { correction }\end{array}$ & $\begin{array}{c}\text { Filtrate } \\
\mathrm{pH}\end{array}$ & \multicolumn{2}{c}{$\begin{array}{c}\text { Filtrate content } \\
{\left[\mathrm{g} \mathrm{m}^{-3}\right]}\end{array}$} \\
\hline & & & & $\mathrm{Cr}^{6+}$ & $\mathrm{Pb}^{2+}$ \\
1 & $1.5: 1$ & 4.0 & - & $\mathbf{4 . 8 0 0}$ & 0.258 \\
2 & $1.5: 1$ & 5.4 & - & $\mathbf{0 . 4 7 0}$ & $<0.2$ \\
3 & $1.5: 1$ & 6.0 & - & $\mathbf{1 . 4 4 0}$ & - \\
4 & $1.5: 1$ & - & 8.72 & $\mathbf{2 . 1 1 0}$ & $<0.2$ \\
5 & $2.0: 1$ & 4.0 & - & $\mathbf{1 . 2 2 0}$ & - \\
6 & $2.0: 1$ & 5.0 & - & $\mathbf{1 . 0 1 0}$ & - \\
7 & $2.0: 1$ & 60 & - & $\mathbf{0 . 0 6 6}$ & - \\
8 & $2.0: 1$ & - & 8.68 & $\mathbf{2 . 7 1 0}$ & $<0.2$ \\
9 & $2.5: 1$ & 4.3 & - & $\mathbf{0 . 9 1 0}$ & $<0.2$ \\
10 & $2.5: 1$ & 5.0 & - & $\mathbf{0 . 0 9 2}$ & $<0.2$ \\
11 & $2.5: 1$ & 6.1 & - & $\mathbf{0 . 0 7 4}$ & $<0.2$ \\
12 & $2.5: 1$ & - & 8.34 & $\mathbf{2 . 7 0 0}$ & 4.57 \\
\hline
\end{tabular}

Further investigations were conducted with wastewater from trench "A". Calcium hydroxide was added to the solution in molar ratios of $\mathrm{Ca}(\mathrm{OH})_{2}$ to $\mathrm{Cr}^{6+}$ of $15: 1$, 20:1,27:1 and 68:1. The molar ratios of $\mathrm{Fe}^{3+}$ to $\mathrm{Cr}^{6+}$ were 3.5:1, 4:1, 5.5:1, 6:1, 7.5:1, 13.3:1 and 15:1. After the addition of calcium hydroxide, the solution was mixed for two hours, then solid iron (II) sulphate was introduced. After a few minutes, without addition of a coagulator, the formation of the solid phase was noticed and after another two hours a separation of the solid phase from the solution was observed. The solution was clear and colourless. The results of these investigations are presented in Table 8. The experiment conducted with the natural wastewater proved that by adding calcium hydroxide and iron (II) sulphate in molar ratios of $\mathrm{Ca}(\mathrm{OH})_{2}$ to $\mathrm{Cr}^{6+}$ and $\mathrm{Fe}^{3+}$ to $\mathrm{Cr}^{6+}$ equal to or higher than 20:1 and 4:1, respectively, the $\mathrm{Cr}^{6+}$ concentration of the wastewater can be decreased to below $0.1 \mathrm{ppm}$.

The results of the X-ray analysis of the precipitates showed that the solid phase, which had formed had an amorphous character with some ettryngite traces (Figure 3(c)). The same sample, having been desiccated at a temperature of $378 \mathrm{~K}$ still retained its amorphous character (Figure 3(d)). According to the chemical reaction presented above one can expect the presence of iron (III) and chromium (III) hydroxides and gypsum in the solid phase. Calcium hydroxide is also expected to be present due to the high quantities of $\mathrm{Ca}(\mathrm{OH})_{2}$ which were added to the solution. The fact that the X-ray analysis could not confirm the presence of calcium compounds, especially of gypsum, which shows peaks even in small concentrations, indicates either their absence (which is very unlikely), or the creation of compounds of the spine type, which can be amorphous. This problem will be the object of further investigations. Introduction of the ash from fluidised hearths instead of calcium hydroxide, led to formation of the components of ash: $\mathrm{SiO}_{2}$ and $\mathrm{Fe}_{2} \mathrm{O}_{3}$, in addition to the ettryngite and the amorphous phases (Figure 3(e)). Gypsum was not detected either, in spite of the fact that the anhydrite is detectable in ash by $\mathrm{X}$-ray radiography. In this case $\mathrm{CaO}$ and $\mathrm{SO}_{4}{ }^{2-}$ had been incorporated in the ettryngite structure. The calcium carbonate, which appeared on the X-ray graphs, was a secondary product, caused by carbonisation.

\section{RECAPITULATION AND CONCLUSIONS}

The geophysical investigations show that the pollutants from chromic heaps are drained by the Regulanka River and carried to the Vistula River. The hydrogeological conditions also indicate, that in the case of an attempt to regulate the river Regulanka and tighten its river-bed, the polluted water is going to migrate to the Vistula through the permeable sediments on the bottom of the Regulanka River valley.

Assuming that all the infiltrates could potentially migrate to the Vistula River, the possibility of draining the polluted waters and cleaning them has been recognized as an option to improve the environment. Decisions were taken to build the two trenches " $\mathrm{A}$ " and " $\mathrm{C}$ " and two draining wells "B" and S-25 in 1998 and at the beginning of 1999. At the same time the initial plan to regulate the Regulanka riverbed along the distance of $1.5 \mathrm{~km}$, had been given up.

The quantity of drained and purified infiltrates, coming from these trenches and draining wells in 1999, was average $900 \mathrm{~m}^{3}$ per day.

Results of investigations into the purification of infiltrates containing $\mathrm{Cr}^{6+}$ demonstrated that such wastewaters could be efficiently purified to chromium concentrations below $0.1 \mathrm{ppm}$ using the following methods:

1) Precipitation of $\mathrm{CrO}_{4}{ }^{2-}$ as lead chromate $\left(\mathrm{PbCrO}_{4}\right)$ using lead (II) salts. The removal of $\mathrm{CrO}_{4}{ }^{2-}$ by precipitation with lead salts should take place at a $\mathrm{pH}$ of 4 to 5 .

At a lower $\mathrm{pH}, \mathrm{Pb}^{2+}$ ions can be observed in solution which at a higher $\mathrm{pH}$, on the other hand, an increased consumption of lead salts is observed, since lead precipitates as hydroxide $\left(\mathrm{Pb}(\mathrm{OH})_{2}\right)$ as a result of hydrolysis. The best results were obtained when the molar ratio of $\mathrm{Pb}^{2+}$ to $\mathrm{Cr}^{6+}$ was to $2.5: 1$.

2) Reduction of $\mathrm{Cr}^{6+}$ with iron (II) salts and precipitation as chromium hydroxide. The most economic combination of reagents assuring the complete precipitation of $\mathrm{Cr}^{6+}$ in this reaction is obtained when the molar ratio of $\mathrm{Fe}^{2+}$ to $\mathrm{Cr}^{6+}$ is $4.5: 1$ and that of $\mathrm{CaO}$ to $\mathrm{Cr}^{6+}$ is $20: 1$. Such ratios guarantee a complete removal of all $\mathrm{Cr}^{6+}$ ions from the solution, even when part of the iron (II) salt is oxidised. With the method based on the incorporation of $\mathrm{CrO}_{4}{ }^{2-}$ into an ettryngite compound, it was possible to remove $94 \%$ of $\mathrm{Cr}^{6+}$, although not to concentrations below $0.1 \mathrm{ppm}$, when iron (III) salt and calcium oxide had been added in large quantities. 
Table 7. Results of experiments to optimise the condition for the removal of chromate ions from a model soluyion containing $104 \mathrm{~g} \mathrm{~m}^{-3}$ $\mathrm{Cr}^{6+}$ and $960 \mathrm{~g} \mathrm{~m}^{-3} \mathrm{SO}_{4}{ }^{2-}$ (initial volume $250 \mathrm{~cm}^{3}$ ) by reduction of $\mathrm{Cr}^{6+}$ to $\mathrm{Cr}^{3+}$ and precipitation of the latter. The letter "P" next to the sequence number indicates that ash was used instead of calcium oxide. The quantities of ash and corresponding quantities of $\mathrm{CaO}$ are given in the second column (No. 9, 10 and 15). The asterisk symbol “*” next to a compound indicates that the compound was introduced to the solution in the first place.

\begin{tabular}{|c|c|c|c|c|c|c|c|c|c|}
\hline \multirow[t]{2}{*}{ No. } & \multicolumn{2}{|c|}{$\begin{array}{c}\text { Quantity of } \\
\text { added compounds [g] }\end{array}$} & \multicolumn{2}{|c|}{ Molar ratios } & \multicolumn{5}{|c|}{ Filtrate characteristics } \\
\hline & $\mathrm{CaO}$ & $\mathrm{FeSO}_{4} \cdot 7 \mathrm{H}_{2} \mathrm{O}$ & $\mathrm{CaO} / \mathrm{Cr}^{6+}$ & $\mathrm{Fe}^{3+} / \mathrm{Cr}^{6+}$ & $\begin{array}{c}\mathrm{Cr}^{6+} \\
{\left[\mathrm{g} \mathrm{m}^{-3}\right]}\end{array}$ & $\begin{array}{c}\mathrm{CaO} \\
{\left[\mathrm{g} \mathrm{m}^{-3}\right]}\end{array}$ & $\begin{array}{l}\mathrm{SO}_{4}^{2-} \\
{\left[\mathrm{g} \mathrm{m}^{-3}\right]}\end{array}$ & $\begin{array}{c}\mathrm{Fe}^{3+} \\
{\left[\mathrm{g} \mathrm{m}^{-3}\right]}\end{array}$ & $\mathrm{pH}$ \\
\hline 1 & $0.42^{*}$ & 0.487 & $15: 1$ & $3.5: 1$ & 2.36 & 587.6 & 1739.4 & - & 11.82 \\
\hline 2 & $0.42^{*}$ & 0.487 & $15: 1$ & $3.5: 1$ & 1.25 & 725.3 & 1706.3 & - & 11.94 \\
\hline 3 & $0.56^{*}$ & 0.487 & $20: 1$ & $3.5: 1$ & 0.79 & 605.0 & - & - & 12.00 \\
\hline 4 & 0.42 & $0.626^{*}$ & $15: 1$ & $4.5: 1$ & $<0.01$ & 650.5 & 2078.9 & 0.04 & 11.68 \\
\hline 5 & 0.42 & $0.626^{*}$ & $15: 1$ & $4.5: 1$ & $<0.01$ & 598.3 & 1675.2 & 0.01 & 11.82 \\
\hline 6 & 0.56 & $0.626^{*}$ & $20: 1$ & $4.5: 1$ & 0.04 & 924.3 & 1982.7 & 0.05 & 11.92 \\
\hline 7 & $0.56^{*}$ & 0.626 & $20: 1$ & $4.5: 1$ & 0.80 & 785.1 & 1638.6 & - & 12.13 \\
\hline 8 & 0.56 & $0.626^{*}$ & $20: 1$ & $4.5: 1$ & $<0.01$ & 678.0 & 1878.7 & 0.07 & 11.85 \\
\hline 9P & $2.8 / 0.56^{*}$ & 0.626 & $20: 1$ & $4.5: 1$ & 1.50 & 967.4 & - & - & 11.82 \\
\hline $10 \mathrm{P}$ & $2.8 / 0.56^{*}$ & 0.626 & $20: 1$ & $4.5: 1$ & 0.05 & 725.3 & 1938.4 & 0.02 & 11.92 \\
\hline 11 & $0.56^{*}$ & 0.750 & $20: 1$ & $5.4: 1$ & 0.01 & 658.9 & 1884.7 & - & 12.05 \\
\hline 12 & 0.56 & $0.750^{*}$ & $20: 1$ & $5.4: 1$ & $<0.01$ & 658.9 & 1882.1 & 0.02 & 12.02 \\
\hline 13 & $0.56^{*}$ & 0.750 & $20: 1$ & $5.4: 1$ & $<0.01$ & 692.3 & 1920.1 & 0.04 & 11.84 \\
\hline 14 & 0.56 & $0.750^{*}$ & $20: 1$ & $5.4: 1$ & $<0.01$ & 647.7 & 1892.4 & - & 11.82 \\
\hline $15 \mathrm{P}$ & $2.8 / 0.56^{*}$ & 0.750 & $20: 1$ & $5.4: 1$ & $<0.01$ & 694.6 & 1789.7 & 0.02 & 12.02 \\
\hline 16 & $0.701^{*}$ & 0.834 & $25: 1$ & $6: 1$ & $<0.01$ & - & - & - & 12.03 \\
\hline
\end{tabular}

Table 8. Results of experiments to optimise the conditions for the removal of chromate ions from wastewater collected in trench " $\mathrm{A}$ " by reduction of $\mathrm{Cr}^{6+}$ to $\mathrm{Cr}^{3+}$ and precipitation of the latter (sample A: $\mathrm{pH}: 7.97, \mathrm{Cr}^{6+}: 38.26 \mathrm{~g} \mathrm{~m}^{-3}, \mathrm{SO}_{4}{ }^{2-}: 407.0 \mathrm{~g} \mathrm{~m}^{-3}, \mathrm{Cl}^{-}: 43.0 \mathrm{~g} \mathrm{~m}^{-3}$, initial volume $250 \mathrm{~cm}^{3}$; sample B: $\mathrm{pH}: 7.98, \mathrm{Cr}^{6+}: 12.99 \mathrm{~g} \mathrm{~m}^{-3}, \mathrm{SO}_{4}{ }^{2-}: 247.0 \mathrm{~g} \mathrm{~m}^{-3}, \mathrm{Cl}^{-}: 43.0 \mathrm{~g} \mathrm{~m}^{-3}$, initial volume $\left.250 \mathrm{~cm}^{3}\right)$. The letter “P” next to the sequence number indicates that ash was used instead of calcium oxide. The quantities of ash and the corresponding quantities of $\mathrm{CaO}$ are given in the second column (No. A6 and B7). The asterisk symbol “*” next to a compound indicates that the compound was introduced to the solution in the first place.

$\begin{array}{lll}\text { No. } & \begin{array}{c}\text { Quantity of } \\ \text { added compounds [g] }\end{array} & \text { Molar ratios }\end{array}$

\begin{tabular}{|c|c|c|c|c|c|c|c|c|c|}
\hline & $\mathrm{CaO}$ & $\mathrm{FeSO}_{4} \cdot 7 \mathrm{H}_{2} \mathrm{O}$ & $\mathrm{CaO} / \mathrm{Cr}^{6+}$ & $\mathrm{Fe}^{3+} / \mathrm{Cr}^{6+}$ & $\begin{array}{c}\mathrm{Cr}^{6+} \\
{\left[\mathrm{g} \mathrm{m}^{-3}\right]}\end{array}$ & $\begin{array}{c}\mathrm{CaO} \\
{\left[\mathrm{g} \mathrm{m}^{-3}\right]}\end{array}$ & $\begin{array}{c}\mathrm{SO}_{4}^{2-} \\
{\left[\mathrm{g} \mathrm{m}^{-3}\right]}\end{array}$ & $\begin{array}{c}\mathrm{Fe}^{3+} \\
{\left[\mathrm{g} \mathrm{m}^{-3}\right]}\end{array}$ & $\mathrm{pH}$ \\
\hline A1 & 0.697 & 0.765 & $68: 1$ & $15: 1$ & $<0.010$ & 1427.0 & - & 0.03 & 12.50 \\
\hline A2 & 0.280 & 0.680 & $27: 1$ & $13.3: 1$ & $<0.010$ & 1109.0 & - & 0.07 & 11.82 \\
\hline A3 & 0.156 & 0.384 & $15: 1$ & $7.5: 1$ & 0.031 & 803.0 & 1497.0 & 0.10 & 9.61 \\
\hline A4 & 0.156 & 0.307 & $15: 1$ & $6: 1$ & 0.080 & 793.2 & 15733 & 0.08 & 10.92 \\
\hline A5 & 0.206 & 0.281 & $20: 1$ & $5.5: 1$ & $<0.010$ & 679.0 & 1579.5 & 0.03 & 11.47 \\
\hline A6P & $1.03 / 0.206$ & 0.281 & $20: 1$ & $5.5: 1$ & 0.020 & 692.7 & 1612.4 & 0.05 & 11.65 \\
\hline $\mathrm{B}^{*} \mathrm{P}$ & $0.35 / 0.07$ & 0.077 & $20: 1$ & $4.4: 1$ & 0.049 & 130.0 & - & 0.03 & 7.96 \\
\hline$B 8^{*}$ & 0.052 & 0.069 & $15: 1$ & $4: 1$ & 1.140 & 174.7 & - & 0.04 & 7.67 \\
\hline $\mathrm{B} 9^{*}$ & 0.070 & 0.070 & $20: 1$ & $4: 1$ & 0.037 & 75.0 & - & 0.02 & 8.09 \\
\hline B10* & 0.052 & 0.061 & $15: 1$ & $3.5: 1$ & 1.620 & 65.0 & - & 0.10 & 7.79 \\
\hline $\mathrm{B}^{*}{ }^{*}$ & 0.070 & 0.061 & $20: 1$ & $3.5: 1$ & 0.310 & 110.0 & - & 0.03 & 8.83 \\
\hline
\end{tabular}

Amongst the methods tested to remove $\mathrm{Cr}^{6+}$ from wastewater the most effective is the method of reducing $\mathrm{Cr}^{6+}$ with the use of iron (II) sulphate in an alkaline environment. It is now being used on an industrial scale. The molar ratio of $\mathrm{FeSO}_{4} \cdot 7 \mathrm{H}_{2} \mathrm{O}$ and $\mathrm{CaO}$ to $\mathrm{Cr}^{6+}$ should be equal to $4.5: 1$ and 20:1 in order to render positive results. After the addition of each reagent, the solution should be mixed for a minimum of 2 hours. When the reaction is almost finished, a coagulant should be added for a faster and more complete separation of the solid 


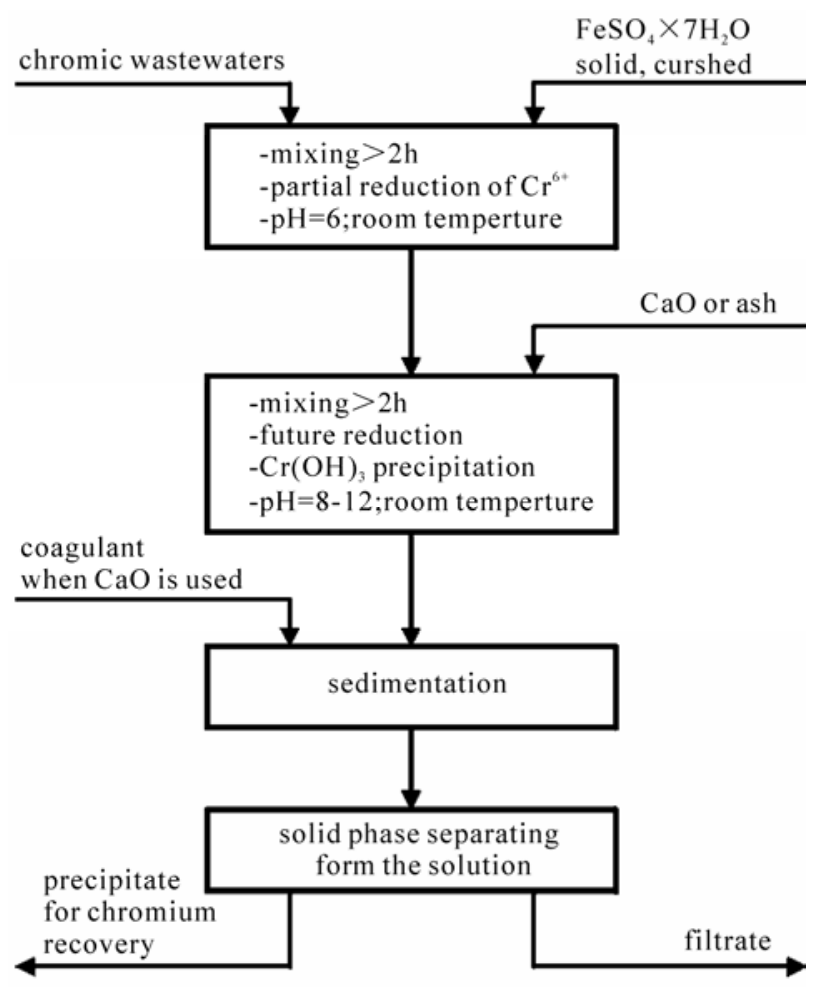

Figure 4. Block diagram showing the removal procedure of chromium (VI) from wastewater in the "Alwernia” Chemical Works.

phases from the solution. When ash is used, no coagulant is necessary. The decisive argument for selecting this method was the fact that it is possible to use precipitates from the infiltrates as raw material for the production of sodium chromate [33].

The following quantities of chemicals are necessary for the wastewater purification:

For each kmol $\mathrm{Cr}^{6+}$ it is necessary to add $4.5 \mathrm{kmols}$ $\mathrm{FeSO}_{4} \cdot 7 \mathrm{H}_{2} \mathrm{O}$ and $20.0 \mathrm{kmols} \mathrm{CaO}$. For each $\mathrm{kg}$ (tonne) $\mathrm{Cr}^{6+}$ it is necessary to add $24.06 \mathrm{~kg}$ (tonnes) $\mathrm{FeSO}_{4} \cdot 7 \mathrm{H}_{2} \mathrm{O}$ and $21.54 \mathrm{~kg}$ (tonnes) $\mathrm{CaO} .1000 \mathrm{~m}^{3}$ of waste from trench “A” with concentration $12.99 \mathrm{~g} \mathrm{~m}^{-3} \mathrm{Cr}^{6+}$ (see Table 8) contained for example $0.25 \mathrm{kmol}$, i.e. $12.99 \mathrm{~kg} \mathrm{Cr}^{6+}$.

The quantities of the main products received from the precipitation of $1 \mathrm{kmol} \mathrm{Cr}^{6+}$ are $1.0 \mathrm{kmol} \mathrm{Cr}(\mathrm{OH})_{3}$ and 4.5 kmols $\mathrm{Fe}(\mathrm{OH})_{3}$. The precipitation of $1 \mathrm{~kg}$ (tonnes) of $\mathrm{Cr}^{6+}$ results in the formation of $1.98 \mathrm{~kg}$ (tonnes) of $\mathrm{Cr}(\mathrm{OH})_{3}$ and $3.08 \mathrm{~kg}$ (tonnes) of $\mathrm{Fe}(\mathrm{OH})_{3}$. These quantities were produced for example from $4000 \mathrm{~m}^{3}$ above-mentioned waste from trench " $\mathrm{A}$ ".

A schematic diagram of this process is presented in Figure 4.

The reduction and precipitation of $\mathrm{Cr}^{6+}$ from wastewater can be conducted at ambient temperature even in winter since the introduction of $\mathrm{CaO}$ causes a rise in temperature. The addition of the chemicals should take place under intensive mixing with the stirrers being in- stalled in such a way that the reagents can be evenly distributed throughout the container.

\section{REFERENCES}

[1] Kowalski, Z. and Mazanek, C. (1998) Sodium chromatematerial flow analysis and technology assessment. Journal of Cleaner Production, 6, 135-142.

[2] Kowalski, Z. and Mazanek, Cz. (1998) Conception of the national model for reusing of chromium wastes. Proceedings of International Conference Environmental Protection in Non-Ferrous Metals and Coal Industry, Szklarska Poręba, Poland.

[3] Kowalski, Z. and Wantuch, W. (1999) Process of solid chrome waste utilization: A Polish experience. Chemical Business, 1, 34-36.

[4] Hydrogeological map of Poland, sheet Kraków (1986). Wydawnictwo Geologiczne, Warszawa.

[5] Kondracki, J. (1978) Geografia fizyczna Polski. PWN, Warszawa.

[6] Guliński, M., Kobiela, K. and Kasicki, T. (1998) Sprawozdanie z badań rozprzestrzeniania się zanieczyszczeń w środowisku gruntowo-wodnym w rejonie składowisk odpadów Z.Ch. Alwernia, Instytut Gospodarki Odpadami w Katowicach (not published).

[7] Kania, S. (1998) Gospodarka wodno ściekowa w Z.Ch. Alwernia, Alwernia (not published).

[8] Official Journal of the European Communities (1994) No. L356/15. Hazardous Wastes According to Article 1(4) of Directive 91689/EEC.

[9] McNeill, J.D. (1980) Electrical conductivity of soil and rocks. Geonics LTD.

[10] Awierbuch, T. and Pawłow, P. (1969) Tiechnołogia sojedinienij chroma. Chimija, Lieningrad.

[11] Szafraniec, J., Szczerburska, T. and Nagel, P. (1986) Badania nad odchromianiem wodnych roztworów na drodze redukcji (VI) siarczynem względnie pirosiaczynem sodowym $\mathrm{z}$ wydzieleniem chromu (III) w postaci wodorotlenku chromowego. Instytut Chemii Nieorganicznej, Gliwice, Poland, (not published).

[12] Humphreys, F.E. and Bailey, A.D. (1969) Tannery effluents: What are the problems? Water Pollution Control, 68, 93-98.

[13] Hunter, R.E. and Spraul, O.J. (1969) Water Pollution Control, 41, 1716.

[14] Koziorowski, A. (1975) Oczyszczanie ścieków przemysłowych. WNT, Warszawa.

[15] Mulokozi, A.M. (1972) The quantitative separation of chromium (VI) from other elements with a strongly basic anion-exchange resin. Analyst, 97, 820-822.

[16] Nriagu, J. and Nieboer, E. (1995) Chromium in natural and human environment. John Wiley et Sons, New York.

[17] Dittrich, V. (1971) Wasser, Luft und Betrieb, 15, 15.

[18] Eru, K. (1964) Wasser, Luft und Betrieb, 8, 603.

[19] Ufimciewa, W.P. and Smietanic, A.D. (1969) Oczistka proizwodstwiennych stocznych wod. Sbornik $\mathrm{Nr}$ 4, Stroijizdat, Moskwa.

[20] Bulewicz, E.M., Kozak, A. and Kowalski, Z. (1997) Treatment of chromic tannery wastes using coal ashes from fluidized bed combustion of coal. Industrial and 
Engineering Chemistry Research, 36, 4381-4384.

[21] Kowalski, Z., Kozak, A. and Bulewicz, E.M. (1997) Method of treating liquid wastes containing chromium compounds. Polish Patent Application, 319201.

[22] Kowalski, Z. and Kozak, A. (1998) A new method for treatment of chromium containing wastes, in Pawlowski et al. (eds.), Chemistry for the Protection of the Environment 3, Plenum Press, New York and London.

[23] Kurowski, W. (1978) Chemia cementu. PWN, Warszawa.

[24] Taylor, H.F.W. (1964) The chemistry of cements. Academic Press, London and New York.

[25] Anthony, E.J., Bulewicz, E.M., Dudek, K. and Kozak, A. (1997) Proceedings of the 14th International Conference Fluidized Bed Combustion, Vancouver, Canada.

[26] Bensted, A. and Prakosh Varma, S. (1971) Studies of ettringite and its derivatives. Cement Technology, 2, 73-76.

[27] Bensted, A. and Prakosh Varma, S. (1973) The lowsulphate form of calcium sulphoaluminate (monosulphate).
Cement Technology, 4, 112-115.

[28] Fela, K., Mazurek, A. and Kozak, A. (1997) Praca Instytutu Chemii i Technologii Chemicznej Politechniki Krakowskiej, Cracow (not published).

[29] Zdral, R. and Kozak, A. (1996) Praca Instytutu Chemii i Technologii Chemicznej Politechniki Krakowskiej, Cracow, Poland (not published).

[30] Hassett, D.J., Pflughoeft-Hassett, D.F. and McGarthy, G.J. (1991) Papers of the 9th International Ash Use Symposium. Vancouver 2.

[31] Woroszyńska, A., Van Leuven, K. and Wilms, D. (1995) Proceedings of the 10th International Conference Chemistry for Protection of the Environment. Lublin, Poland.

[32] Aleksiejew, W. (1966) Analiza jakościowa. PWN, Warszawa.

[33] Kowalski, Z. and Walawska, B. (1997) Utilization of chrome tannery wastes into sodium chromate production process. Polish Journal of Applied Chemistry, 41, 385-418. 